\title{
How Entrepreneurs Can Thaw Their Frozen Social Networks
}

\author{
Ben Spigel (University of Edinburgh Business School) \\ Kautsar Ramli (University of Bristol)
}

KEYWORDS: crisis management, COVID-19, Networking.

Networks are one of the most important resources entrepreneurs can have. Indeed, one of the few consistent findings in entrepreneurship research is that networks matter. Entrepreneurs with bigger and more diverse networks will do better than those with smaller and more homogeneous networks.

But the lockdowns caused by the Covid-19 pandemic cut off entrepreneurs from their networks. As one FinTech entrepreneur told us recently, "I haven't met anyone new in the past year." No longer able to go to meetings, conferences, events, or informal meetings, it's harder for entrepreneurs to build new relationships and maintain their existing ones. In essence, entrepreneurs' networks have been frozen for over a year.

Based on everything that we know about how entrepreneurship works, this is a very bad thing. Entrepreneurs and those who support them - from policymakers in government to economic development organizations to ecosystem builders - need to think carefully about the consequences of these frozen networks and what they can do to reverse this trend as the world emerges from the pandemic.

We investigated entrepreneurs' networking activities as part of the ERICC (Entrepreneurial Resilience, Innovation, and Change during the Covid-19 Crisis) Project, a UK Research and Innovation (https://www.ukri.org) -funded project looking at the pandemic's impact on high-growth entrepreneurs throughout the UK. As part of this research, we are conducting ongoing interviews with entrepreneurs to track how they are reacting to the ever-changing nature of this crisis. So far we have conducted more than 200 interviews with nearly 100 entrepreneurs in sectors ranging from FinTech to food production, and from central London to Leeds to the Scottish Borders.

Our data suggest that entrepreneurs have used their

networks less and less as the pandemic has dragged on. While earlier in the crisis, many entrepreneurs turned to their existing networks of other entrepreneurs via WhatsApp or Slack groups to brainstorm how to deal with the early problems of lockdown, this has become less common over time. But as the pandemic continued, entrepreneurs were no longer keen to use these platforms due to their limitations in having real connections within their network. A Glasgow-based entrepreneur explained that: "Sometimes you feel like you've got to have a reason to set up a Zoom call -- it feels like a big deal -- whereas before, I was based in a place where you could just turn around and go, oh, does anyone got an accountant that they would recommend?"

\section{Networks in a Crisis}

Entrepreneurs use their networks to help their company in three major ways: finding investors, finding customers, and finding peer support. First, as entrepreneurs begin to look for new investment, they are encountering new challenges trying to connect with investors whom they've never been able to meet face-toface. This has made it difficult for them to move beyond the pitch and get the inside perspective about what the investor is looking for. A technology entrepreneur in Edinburgh told us: "Even with a fairly horrid face-to-face meeting with a busy VC, they tend to see you to the door afterwards. You shake hands and you say: what are you doing next?" The lack of face-to-face contact with investors means that it's harder to build and close funding deals.

Second, networks also help entrepreneurs find new customers because they can use connections to get introductions to potential decision-makers. These interactions generally happen through informal meetings, for example, over drinks at a global conference or from a suggestion over coffee with a local contact. These types of conversations have proven

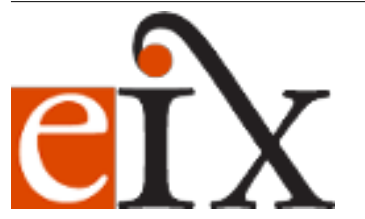

Copyright ( ) 2021 The Authors. Entrepreneur \& Innovation Exchange is published at EIX.org. This is an open access article under the terms of the Creative Commons Attribution-NoDerivs License, which permits use and distribution in any medium, provided the original work is properly cited and no modifications or adaptations are made. View EIX.org Authorship Terms at https://eix.org/terms 
difficult since the pandemic's onset. While many entrepreneurs have been able to shift more resources to digital marketing, this is not as effective as referrals and introductions, particularly for companies targeting enterprise-level customers.

Finally, the lockdown has made it difficult for entrepreneurs to talk with one another and help one another. Entrepreneurs build their networks at events in their local and business ecosystems and through their informal, random encounters within their communities. Without the ability to engage in face-to-face conversation, entrepreneurs' power to build peer-topeer networks has been effectively eliminated. This is due to both the barriers to getting in contact with one another and the scale of the internal challenges entrepreneurs are facing, which leaves little time to talk to others. As one entrepreneur told us: "Whilst the community exists, unfortunately, for start-ups and this kind of stuff...it's a hard thing to do, and so what you can do is look after your [firm] or your interests."

This issue is particularly challenging for newer entrepreneurs who don't have a pre-existing network of other founders that they can turn to for advice and support during the pandemic. This makes it very challenging for entrepreneurs to come up with solutions to common problems, such as motivating workers during the lock-down or getting suggestions on how to approach investors. This has weakened the power of many local entrepreneurial ecosystems.

These problems paint a troubling picture for entrepreneurs. One of the few consistent findings in entrepreneurship research is that networks matter. No matter the type of entrepreneur, the sector, or the place, entrepreneurs with bigger networks do better than those with smaller ones. ${ }^{1}$ Right now it's still too early to see the full consequences of frozen networks, but anecdotally our interviews show that entrepreneurs are having trouble finding new customers or getting introduced to new investors or other gatekeepers. These challenges make it harder to engage in the types of innovative activities that will power future growth. We also know that networks are key for entrepreneurs' emotional health. We should be concerned that smaller networks mean that founders will get less emotional support, which may lead to burnout and a loss of growth ambition. These are all major problems that threaten both entrepreneurs and the economic prosperity they create for their communities.

\section{Tackling remoteness through the use of networks}

In essence, entrepreneurs' networks have been frozen for the past year. A year without network building will have consequences, not just for business during the pandemic but also for years to come. Coming out of the remoteness, entrepreneurs' networks will be smaller than they were before. Many business relationships have weakened over the past year due to lack of contact (see Figure 1). These weaker networks will make it harder for entrepreneurs to access the resources they need to innovate and scale for years to come. Lack of connections with investors through entrepreneurs' social networks will make it more difficult to negotiate deals. Entrepreneurs will face similar challenges in trying to leverage their networks to find new customers and partners. Similarly, they will be less able to draw on dense networks of other founders to help overcome common challenges. Because networks are self-reinforcing - contacts introduce each other to new contacts - even when networking opportunities return to their pre-Covid levels, entrepreneurs' networks will still be smaller than they would have been otherwise. The effects of frozen networks will persist years after the crisis, potentially limiting growth and adaptability.

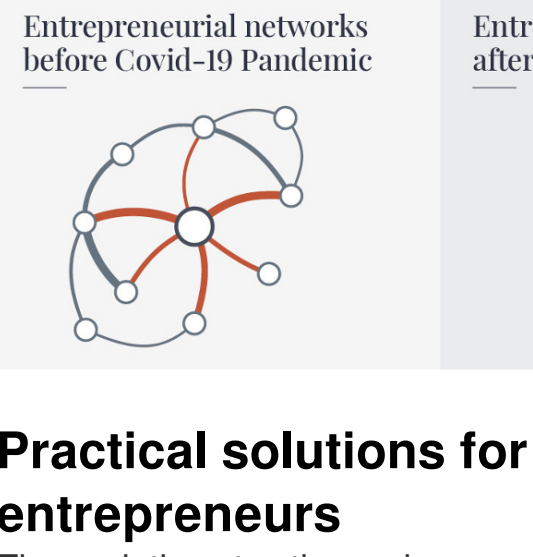

The solution to these issues is not more online networking events. Many of our interviewees tried these at the start of the crisis but did not find them helpful. The same can be said for online versions of industry conferences and trade fairs. Despite rapid innovations to allow online events to provide the authentic experience and unplanned conversations found at faceto-face ones that help entrepreneurs build and leverage their networks, nothing replaces the serendipity of just being there.

One way of addressing this is to simply make the 
business community aware of the issue and the types of challenges smaller networks are likely to cause. Entrepreneurs should think carefully about the quality of their networks and the types of resources they can access through them. As some places exit strict lockdown, entrepreneurs should proactively reach out to people in their pre-pandemic networks to catch up and rebuild their relationships. Ecosystem leaders should prioritize organizing meetups as the pandemic eases and face-to-face events become possible. These events should seek to create new opportunities for members of the local entrepreneurial community to meet new people, build new connections, and learn from one another. The purpose of this is to help entrepreneurs reconnect not just with one another but also with the act of sharing their experiences with others and learning from them. The focus doesn't have to be on specific skills or technologies; it should emphasize building relationships and helping new entrepreneurs establish their own networks. Event organizers will have to work hard to ensure that events do more than just reintroduce old friends to one another. Every event should create new bonds between founders.

Nevertheless, ecosystem builders should also take this pause in face-to-face activities to build more inclusive and open events to bring the community together in the post-pandemic environment. As firms continue to have remote or hybrid-working structures, evening events at a city bar will be even less accessible than they were before the pandemic. Ecosystem leaders should look for ways to increase the diversity of attendees by reaching out to those who have not been included before and look for ways to extend their reach through their choices of location, venue, formats and topics.

For example, event organizers should be mindful that not everyone can attend afterwork events in the evenings, especially if they have caregiving duties. Breakfast or lunch-time events help get around these barriers. Organizers need to make the events more enticing, with new content that draws people in and, of course, great food! Similarly, ecosystem leaders must proactively engage with the new entrepreneurs who started during the pandemic, by reaching out to them and finding out what types of events and support they need, and then working to provide it. We cannot assume that new entrepreneurs will have the same needs as those who started before the pandemic.

Entrepreneurs should respond to these challenges by reflecting on how frozen networks might affect their growth trajectory. Some businesses may be less affected by these changes than others. For example, those who do not need to raise investment in the near term may be less affected than enterprise B2B firms that need to raise money and make sales quickly. Entrepreneurs should think about ways that they can continue maintaining and building their networks during the pandemic and about how this can be accelerated as the lockdown eases. They will play a very important role in helping to accelerate network development after the pandemic. This network growth should focus on building better networks rather than just networking for networking's sake. This means helping to broker highquality introductions and finding ways to make entrepreneurs' networks more inclusive and bring new entrepreneurs into the community. While this has always been important, the pandemic and the isolation it caused has made it even more so.

Most importantly, entrepreneurs and ecosystem leaders need to listen carefully to founders and business owners to look for emergent trends in the challenges they're facing. The nature and nuances of the Covid-19 pandemic have constantly changed over time, with new challenges emerging as the business and health environment changes. But it can be hard to recognize these new changes and how they are affecting the wider business community. Working together, all the different members of entrepreneurial ecosystems around the world need to stay aware of the invisible entrepreneurial challenges as the world recovers from the pandemic.

\section{References}

1. Stam, W., Arzlanian, S., \& Elfring, T. (2014). Social capital of entrepreneurs and small firm performance: A meta-analysis of contextual and methodological moderators. Journal of Business Venturing, 29(1), 152-173.

https://doi.org/10.1016/j.jbusvent.2013.01.002 